University of Massachusetts Amherst ScholarWorks@UMass Amherst

Resource Economics Department Faculty

Publication Series

Resource Economics

1984

\title{
An Institutional Perspective on Corporate-Control and the Network of Interlocking Directorates
}

JA CASWELL

Follow this and additional works at: https://scholarworks.umass.edu/resec_faculty_pubs

\section{Recommended Citation}

CASWELL, JA, "An Institutional Perspective on Corporate-Control and the Network of Interlocking Directorates" (1984). Journal of Economic Issues. 66.

$10.1080 / 00213624.1984 .11504262$

This Article is brought to you for free and open access by the Resource Economics at ScholarWorks@UMass Amherst. It has been accepted for inclusion in Resource Economics Department Faculty Publication Series by an authorized administrator of ScholarWorks@UMass Amherst. For more information, please contact scholarworks@library.umass.edu. 


\title{
An Institutional Perspective on Corporate Control and the Network of Interlocking Directorates
}

\author{
Julie A. Caswell
}

The network of contacts between individuals in positions of power in the corporate system can be approached from two separate but complementary perspectives. The first views the network as a sociological phenomenon-as a system for socializing members or potential members of the upper class in those skills and attitudes necessary for replication of the current system. The second perspective sees the network as a pragmatic means to an economic end, the end being higher profits in the corporate sector and the means being the exchange of information and coordination of policy between members of the system.

The coexistence of distinct but heavily overlapping networks of contact parallels these perspectives. Networks of contact established through attendance at exclusive preparatory schools and colleges and through membership in select social and civic organizations may primarily serve the first function of socialization and generation of group cohesiveness [Domhoff 1967 , pp. 12-37]. Corporate interlocking directorates may primarily serve the second function of coordinating activity and arbitrating conflict in order to enhance corporate profit performance. Private policy planning groups such as the Conference Board may, on the other hand, serve both socialization and coordination functions [Dye 1978].

The major issue of interest in study of these networks is whether their

The author is Assistant Professor of Agricultural \& Resource Economics, University of Massachusetts, Amherst. This article was presented at the Annual Meeting of the Association for Evolutionary Economics, San Francisco, 27-30 December 1983. 
existence constitutes evidence that control over corporate and government decision making is centralized. In other words, the issue is whether elitist or pluralist views of the organization of our institutions are correct. This article focuses on the implications for corporate control of one of these networks of contact, the system of corporate interlocking directorates. At the same time, it attempts to integrate network analysis with the large body of work on direct control of corporations through stockholding.

\section{Control in the Corporate Sector}

Analysis of corporate control has followed two mostly separate tracks. The first looks at direct control over corporate decision making through stockholding or stockholding combined with representation on boards of directors [Berle and Means 1932; Larner 1970; Kotz 1978]. On this actor level, control is conceptualized as a dyadic, hierarchic relationship between two firms, a firm and a family or individual, or a firm and a financial institution. The body of literature developed on management control is on this level of analysis. The striking features of this approach is its treatment of the firm as an independent entity operating free of centers of control outside its management and stockholders. As such it is consistent with the bulk of economic analysis that also assumes independent, albeit in some cases collusive, decision making by firms.

The second track of analysis conceptualizes control as being exercised through a network of relationships between firms. Authors using this approach argue that a firm's individual one-to-one relationships can be properly analyzed only in the context of the entire set of relationships maintained by the firm and all other firms in the relevant network [Bearden et al. 1975, pp. 24-29; Mizruchi 1982, p. 52]. The network of relationships used to study corporate control is commonly the set of interlocking directors, since the board of directors has the power to exercise control over the corporation.

Direct control is a familiar concept to economists and study of it has been extensive. The focus of this research has been to ascertain who exercises control, primarily through stockholding, over the decision making process within the large firms that dominate the U.S. economy. In the early 1900s, this control was widely believed to be held by a "Money Trust" of large financiers [Brandeis 1914; Moody 1919]. Adolph A. Berle and Gardiner C. Means introduced the idea of a managerial revolution when they suggested in the 1930s that management discretion was increasing as stockholding in large firms became more dispersed [Berle and Means 1932]. Studies done in the 1960s and 1970s have variously found 
high levels of managerial control [Larner 1970], family control [Burch 1972], and financial control [Kotz 1978]. Even though the diverse research methodologies and samples used by these authors have yielded mixed results, the conventional wisdom has remained that, by and large, management control is widespread among large firms in the United States.

The suspected dominance of management control has lead to a strong interest in the motivations and business strategies of managers versus owners. Numerous studies of the most widely discussed hypothesis, that owner-controlled firms are more profitable than those controlled by management, have not found consistent evidence in its support [Bothwell 1980, pp. 303-305]. This is not surprising for two reasons. The first, not pursued here, is that the studies may show no difference between the groups because there is a high level of miscategorization of firms by control type. In particular, in cases where limited data are available on family or financial control, firms that do have centers of control may be mistakenly categorized as management-controlled [Burch 1972].

The second explanation is that information on direct control is insufficient in itself to assess the control a firm is under. Firms operate in an environment made up of direct holders as well as other firms and institutions that may have financial or business relationships with the firm and may have board representation. As linkages between families and firms are assessed in the context of a network of relationships, control is clearly relative to how many actors are involved in a decision, the degree of their interest, and how much influence they are willing to exercise. The process of corporate decision making is, therefore, analogous to political decision making, where "interest groups" vie for control over corporate resources. It is also analogous in that certain parties to the decision may have the power necessary to determine the outcome regardless of opposition. A family-controlled firm with no debt, for example, may be able to make its decisions without consultation with other parties while a highly leveraged management-controlled firm may have its scope of action severely limited by loan covenants.

The network analysis techniques used in the study of interlocking directorates are not generally familiar to economists. This is probably a result of the focus of economic analysis on competitive relationships. Such relationships assume the independence of the actors involved. Network relationships such as those represented by the system of interlocking directors form an institutional superstructure within which market level competition or rivalry occurs. As such they form a nexus between competition and coordination and point to extramarket mechanisms that affect economic performance. 
The major difficulty in using interlocking directorships to study control of corporate decision making is that their function and content are variable and basically unverifiable. As with networks of social, civic, and political ties, the network of interlocking directorates is a complex institution that serves several functions simultaneously. Since business decision making and board meetings are not public, outsiders can gain only hearsay information on internal corporate matters from the business press. Thus direct evaluation of the effects of this network are not possible. Its longevity and stability, however, argue for its importance and the need to study network forms of control [Dooley 1969, p. 322; Allen 1974, p. 404; Bunting 1976, pp. 28-32; Mizruchi 1982, pp. 177-78].

\section{The Function and Content of Interlocking Directorates}

The study of interlocking directorates as an institution of corporate control requires the development of a conceptual framework outlining their function and content. The legislative history of Section 8 of the Clayton Act of 1914, which restricts interlocking directorates, indicates that the major concern raised by the practice of interlocking directors was its effect on business decision making and the level of competition between firms [Kramer 1950; Halverson 1976]. These ties were, therefore, viewed as indicative of alliances or control relationships between corporations as well as the means of carrying them out. Work done since the 1930s has broadened the issues addressed in studies of interlocking directors and system level control from what can be characterized as concerns with maintenance of competition to issues of the existence and replication of an elite class within American society.

Three authors recently have presented typologies of the possible content and function of interlocking directorates [Koenig, Gogel, and Sonquist 1979, pp. 174-77; Mizruchi 1982, pp. 34-44; Palmer 1983, pp. 4042]. A synthesis of these typologies yields five basic approaches to the study of interlocking directorates. The first approach constitutes the null hypothesis: exchange of directors is not significant because board members are figureheads in the governance of firms. Control over the firm rests with management, which chooses outside directors based on friendship or prestige factors. In this view, linkages through interlocking directors have no content and serve secondary or basically frivolous functions.

A second approach views exchange of directors as a sociological phenomenon. The system of interlocking directors is seen as a means of consolidating and maintaining general control over the corporate sector by an upper class of American society. Interlocks are not important as rela- 
tionships between specific firms, but as a diffuse set of social relations that facilitates formation of group consensus and socializes new members of the class [Koenig, Gogel, and Sonquist 1979, pp. 176-77]. The content of intercorporate personnel ties is, therefore, relationships between upperclass individuals and their function is to buttress general upper-class control.

The three remaining approaches emphasize economic motivations for intercorporate ties. In each case, one or the other or both of the firms involved seek contact with the other firm in order to advance their economic interests. Mark Mizruchi labels these three approaches coordination, cooptation, and control. [Mizruchi 1982]. The basic differences between them is in the conceptualization of the power relationships between the firms. From the coordination perspective, interlocking directors are a means of harmonizing policy for mutual benefit. The important characteristic of these types of ties is their reciprocal nature-the parties are involved in a non-hierarchical relationship. The content of interlocking directorates, from this perspective, is ties between firms that have regular exchange or market contact with each other and the function is to coordinate mutually beneficial policy.

The remaining two paradigms view interlocks as hierarchical relationships. The cooptation or resource dependency paradigm, relying on a management control perspective, views the firm as an independent entity under management direction that actively seeks to place on its board people affiliated with other firms that control resources crucial to its operation. These people are coopted in the sense that their intimate contact with the firm makes it possible for the management to gain their support and cooperation. In contrast to the coordination view, the relationship is hierarchical in that only one member of the pair is active and powerful while the other subordinates its interests to some degree. The content of interlocking directors is again ties between firms that have a regular exchange or market contact, but the function is to allow one firm to be more effective through cooptation of the other.

The final perspective views intercorporate ties as a control relationship through which one firm dictates or influences the other firm's policies for its own benefit. The relationship is hierarchical, as with cooptation, but the flow of influence is assumed to be in the opposite direction. The same relationship can often be interpreted from both perspectives. For example, Donald R. Grangaard was president, chief executive officer, and director of First Bank System, Inc. (Minneapolis) in 1976. He was also a director of George A. Hormel \& Company. This interlock can be viewed alternatively as a move by Hormel to coopt First Bank System, a source 
of capital, or as a move by First Bank System to place its representative on Hormel's board to monitor and influence corporate policy.

From the standpoint of economic analysis, the last three perspectives are most relevant. Although the system of interlocking directorates undoubtedly serves to generate cohesiveness within the upper class in the United States and this may have indirect effects on economic performance, the possible market-level coordinating effects of this network have more direct implications for performance. The magnitude of these effects depends on the structure and strength of ties between firms. If ties tend to be dyadic and each firm has only a few such ties, the overall effect will probably be less than if groups of firms are closely interlocked regardless of whether one views the ties as serving a coordination, cooptation, or control function. On the other hand, whether the tie is hierarchic (reflects the ability of one firm to direct the other's policy) is also an important determinant of how much impact the network of interlocking directors will have on market behavior.

For development of an analytical base for research on interlocking directorates it is probably not necessary to choose between the coordination, cooptation, and control paradigms. This is especially true since some proportion of these ties likely fit each of the three paradigms. A useful perspective growing out of these approaches is that interlocks reflect working relationships between firms and are pursued in order to establish regular forums for exchange of information. The strength of influence in many cases is such that it constitutes a control relationship in which firms cease to be independent decision making centers.

\section{Direct and Network Corporate Control}

Patterns of corporate control indicate the degree of centralization of economic, political, and social power in the United States. Clearly, the less diffuse this power is, the less competitive and democratic our system. Analysis of the level of centralization requires data on both direct and network control and its integration into an overall control picture.

Direct control of individual corporations through stockholding and related board representation is the widely researched level of the control structure. The findings indicate a shifting distribution of owner, financial, and management control over time. These results shed light on the power structure of intra-corporate decision making and have implications for the independence of that decision making.

Inferences on the structure of control drawn at the level of direct control alone, however, are misleading. In particular, the absence of direct 
control does not indicate that network forms of control will also be absent. On the contrary, recent research on patterns of control in the agribusiness sector indicates that strong direct control is associated with the absence of network ties through interlocking directors while firms without strong centers of control (the so-called management-controlled firms) have higher levels of network ties [Caswell 1984]. This line of reasoning leads to the conclusion that the managerial revolution may be more properly thought of as a shift in the locus of control to a higher institutional level of control [Bunting and Mizruchi 1982].

A corollary to the argument that the presence of this type of network level control or influence implies less dispersion of control than is otherwise recognized is that conventional measures of aggregate concentration in the economy are understated. Yet, the system of corporate interlocking directors is only one facet of the network of interpersonal and intercorporate ties between people and firms in positions of power within the U.S. system. Analysis of those institutions of control is an essential element in understanding the functioning of economic markets as well as governmental, education, and social processes. A useful analytical approach to the study of control in the corporate sector is to distinguish between patterns of direct and network control and build a paradigm that integrates the findings of each.

\section{References}

Allen, M. P. 1974. "Structure of Interorganizational Elite Cooptation: Interlocking Corporate Directorates." American Sociological Review 39 (June): 393-406.

Bearden, James, William Atwood, Peter Freitag, Carol Hendrichs, Beth Mintz, and Michael Schwartz. 1975. "The Nature and Extent of Bank Centrality in Corporate Networks." Paper presented at annual meeting of American Sociological Association.

Berle, A. A., and Gardiner Means. 1968. The Modern Corporation and Private Property. 1932; reissued New York: Harcourt, Brace and World.

Bothwell, James L. 1980. "Profitability, Risk, and the Separation of Ownership from Control." The Journal of Industrial Economics 28 (March) : 30311.

Brandeis, Louis. 1914. Other People's Money. New York: Frederick A. Stokes.

Bunting, David. 1976. "Corporate Interlocking Part II: The Modern Money Trust." Directors and Boards 1 (Summer) : 27-37.

Bunting, David, and Mark S. Mizruchi. 1982. "Transfer of Control in Large Corporations." Journal of Economic Issues 16 (December) : 985-1004.

Burch, Philip H., Jr. 1972. The Managerial Revolution Reassessed. Lexington, Mass.: Heath.

Caswell, Julie A. 1984. "Direct Stockholding and Network Interlocking Di- 
rectorate Control of Firms in the Agribusiness Sector, 1976." Ph.D. diss., University of Wisconsin, Madison.

Dooley, Peter C. 1969. "The Interlocking Directorate." American Economic Review 59 (June) : 314-23.

Domhoff, G. William. 1967. Who Rules America? Englewood Cliffs, N.J.: Prentice-Hall.

Dye, T. R. 1978. "Oligarchic Tendencies in National Policy-Making: The Role of the Private Policy-Planning Organizations." Journal of Politics 40 (May) : 309-31.

Halverson, James. 1976. "Interlocking Directorates-Present Antitrust Enforcement Placed in Proper Perspective." Villa Nova Law Review 21 (March) : 393-409.

Koenig, T., R. Gogel, and J. Sonquist. 1979. "Models of the Significance of Interlocking Corporate Directorates." American Journal of Economics and Sociology 38 (April) : 173-86.

Kotz, David M. 1978. Bank Control of Large Corporations in the United States. Berkeley: University of California Press.

Kramer, Victor H. 1950. "Interlocking Directorships and the Clayton Act After Thirty-Five Years." Yale Law Review 59: 1266-75.

Larner, Robert J. 1970. Management Control and the Large Corporation. Cambridge, Mass.: University Press, Dunellen.

Mizruchi, Mark. S. 1982. The American Corporate Network 1904-1974. Beverly Hills, Calif.: Sage Publications.

Moody, John. 1919. The Masters of Capital. New Haven, Conn.: Yale University Press.

Palmer, Don. 1983. "Broken Ties: Interlocking Directorates and Intercorporate Coordination." Administrative Science Quarterly 28 (March): 40-55. 